\title{
PORT STATE JURISDICTION IN NEW ZEALAND: THE PROBLEM WITH SELLERS
}

\author{
Bevan Marten*
}

This article discusses the decision of the New Zealand Court of Appeal in Sellers v Maritime Safety Inspector [1999] 2 NZLR 44. It is not critical of the Court's approach to the use of international law in domestic courts, but instead argues that the decision represents an incorrect view of international law regarding a port state's jurisdiction over visiting foreign vessels. It argues that the Court was wrong to characterise New Zealand's maritime safety agency's use of s 21 of the Maritime Transport Act 1994 as an attempt to regulate such vessels on an extraterritorial basis, and that port states do possess the jurisdiction to introduce unilateral measures of the kind promoted by the agency in that case. The article argues that the decision in Sellers is exercising a negative impact over New Zealand's maritime regulatory efforts and that Parliament should address the issue by way of amending legislation.

\section{INTRODUCTION}

Decided in 1998, Sellers v Maritime Safety Inspector continues to exercise a negative influence over New Zealand's maritime law. ${ }^{1}$ Concerning a yachtsman's refusal to carry a radio, it provided a rare example of a domestic court grappling with the extent of a state's prescriptive jurisdiction over foreign vessels under international law. The decision has been discussed by several international law scholars, the most convincing of whom have argued that the reasoning in the judgment is flawed, and that the conclusions reached do not accurately reflect international law. ${ }^{2}$ However, to date it has

* Lecturer, Faculty of Law, Victoria University of Wellington. This article draws on material from the author's monograph Port State Jurisdiction and the Regulation of International Merchant Shipping (Springer, Heidelberg, 2013).

1 Sellers v Maritime Safety Inspector [1999] 2 NZLR 44 (CA).

2 See Erik J Molenaar "Port State Jurisdiction: Towards Comprehensive, Mandatory and Global Coverage" (2007) 38 Ocean Dev \& Intl L 225 at 231-232; Henrik Ringbom The EU Maritime Safety Policy and International Law (Martinus Nijhoff Publishers, Leiden, 2008) at 339; compare Dermott Devine "Port State Jurisdiction: A contribution from New Zealand" (2000) 24 Marine Policy 215; Z Oya Özçayir Port State Control (2nd ed, LLP, London, 2004) at 90. 
received little academic attention in New Zealand, despite its ongoing impact on maritime law and policy in this jurisdiction.

This article provides a critique of the decision, focusing on the Court of Appeal's conclusions that the legal requirements in question involved extraterritorial elements, and that New Zealand's prescriptive jurisdiction as a port state is limited to only those matters contained in international agreements. It argues that the influence of Sellers is preventing New Zealand from exercising a full range of regulatory options in relation to foreign vessels, and recommends that the decision be overturned.

\section{THE CONCEPT OF PORT STATE JURISDICTION}

Port state jurisdiction refers to the jurisdiction a state may exercise over foreign vessels visiting its ports. ${ }^{3}$ It can be contrasted with flag state jurisdiction (the jurisdiction a state has over the vessels operating under its flag) and coastal state jurisdiction (the jurisdiction a state has over its maritime zones such as the territorial sea and exclusive economic zone). Port state jurisdiction warrants separate treatment from coastal state jurisdiction more generally for a combination of legal and practical factors. As Crawford notes: ${ }^{4}$

Quite aside from matters relating to the internal economy of ships, port state jurisdiction is increasingly recognized as a remedy for the failure of flag states to exercise effective jurisdiction and control of their ships. The jurisdiction is no longer used solely to enforce local questions of civil and criminal law, but is actively playing a role in the international regulatory sphere.

In legal terms the concept is characterised by the subjection of visiting vessels to the state's territorial jurisdiction, providing a sound basis for the exercise of both prescriptive and enforcement jurisdiction. ${ }^{5}$ As the United Nations Convention on the Law of the Sea (UNCLOS) confirms, a

3 The concept goes well beyond the jurisdiction over pollution events provided for in art 218 of the United Nations Convention on the Law of the Sea 1833 UNTS 3 (opened for signature 10 December 1982, entered into force 16 November 1994) [UNCLOS], which is headed "port state jurisdiction". Although the label was only popularised post-UNCLOS, the notion of a state exercising authority over foreign vessels visiting its ports is of course far older. For more detailed overviews of the concept see Ringbom, above n 2; Erik J Molenaar "Port State Jurisdiction" in Rüdiger Wolfrum (ed) The Max Planck Encyclopedia of Public International Law (online ed, Oxford University Press, Oxford, 2010). On art 218 see Ted L McDorman "Port State Enforcement: A Comment on Article 218 of the 1982 Law of the Sea Convention" (1997) 28 J Mar L \& Comm 305

4 James Crawford Brownlie's Principles of Public International Law (8th ed, Oxford University Press, Oxford, 2012) at 465.

5 The legal issues arising in the context of port state jurisdiction are primarily those concerning prescriptive jurisdiction. When enforcement is required the vessel is present within the port state's territory and, provided the exercise of prescriptive jurisdiction is valid, will be uncontroversial. 
state's territorial sovereignty extends over both its internal waters (for example harbours and bays) ${ }^{6}$ and territorial sea (12 nautical miles out from land). ${ }^{7}$ Although authors disagree as to the extent of a port state's jurisdiction over a visiting foreign vessel, it is universally accepted that such vessels are subject to that jurisdiction in general terms, notwithstanding the flag state's concurrent jurisdiction. ${ }^{8}$

Port State Jurisdiction is distinguishable from territorial jurisdiction more broadly on the basis of the foreign-flagged vessel's right of innocent passage through the territorial sea, ${ }^{9}$ which Beale described as the "chief limitation of a sovereign's jurisdiction over his own territory". ${ }^{10}$ Where vessels passing through the territorial sea in accordance with this right are concerned, art 21 of UNCLOS sets out an exhaustive list of the coastal state's regulatory options. It essentially limits coastal states to regulating specific aspects of shipping, such as environmental and navigation safety issues, and in most cases only in accordance with generally accepted international standards. A state could apply its laws to all those vessels passing through the territorial sea whose passage is not "innocent", but the situations in which this will occur go well beyond the ordinary operations of merchant vessels. ${ }^{11}$

By contrast, UNCLOS provides almost no guidance (or limitations) on prescriptive jurisdiction exercised over vessels voluntarily visiting a state's ports or internal waters. ${ }^{12}$ This was a deliberate decision at the time the agreement was being negotiated, the result of which is to leave questions of port state jurisdiction to be determined in accordance with international law. ${ }^{13}$ As UNCLOS states

6 The port state jurisdiction concept cannot be equated with "internal waters jurisdiction", as some ports are located within the territorial sea.

7 UNCLOS, above n 3, art 2. Archipelagic waters, where relevant, also fall within this group.

8 See for examples Myres S McDougal and William T Burke The Public Order of the Oceans: A Contemporary International Law of the Sea (Yale University Press, New Haven, 1962) at 94-97 and 156157; V D Degan "Internal Waters" (1986) 17 Netherlands YB Intl L 3 at 22; The American Law Institute Restatement of the Law Third: The Foreign Relations Law of the United States (American Law Institute Publishers, St Paul, 1987) vol 2 at 36 and 42; R R Churchill and A V Lowe The Law of the Sea (3rd ed, Manchester University Press, Manchester, 1999) at 65; Crawford, above n 4, at 464.

9 UNCLOS, above n 3, pt II, s 3; see Crawford, above n 4, at 317. The situations in which passage can be described as non-innocent go well beyond the ordinary operations of merchant vessels: see UNCLOS, above n 3, art 19.

10 Joseph H Beale "The Jurisdiction of a Sovereign State" (1923) 36 Harv LR 241 at 259.

11 See UNCLOS, above n 3, art 19.

12 Some limited references to port entry conditions are made, see UNCLOS, above n 3, arts 25(2) and 211(3).

13 Erik J Molenaar Coastal State Jurisdiction over Vessel-Source Pollution (Kluwer Law International, The Hague, 1998) at 94; David Anderson "Port States and Environmental Protection" in Alan Boyle and David Freestone (eds) International Law and Sustainable Development: Past Achievements and Future Challenges (Oxford University Press, Oxford, 1999) at 342; Churchill and Lowe, above n 8, at 60-61; Lindy S Johnson Coastal State Regulation of International Shipping (Oceana Publications Inc, Dobbs Ferry, 2004) at 35 and 46. 
in its preamble, any "matters not regulated by this Convention continue to be governed by the rules and principles of general international law". Putting aside the limitations on prescriptive jurisdiction relating to vessels enjoying sovereign immunity, ${ }^{14}$ or those in distress, ${ }^{15}$ international law discloses no shipping-specific ${ }^{16}$ limits on the extent of port state jurisdiction. ${ }^{17}$ As a result it is a very effective basis for the regulation of foreign vessels when compared with coastal state jurisdiction more generally.

In practical terms port state jurisdiction is characterised by having the vessels a state intends to regulate in a convenient location for the purposes of inspection and enforcement. This is of course far safer and more efficient than attempting enforcement at sea. Accordingly, while it is legally possible to extend a law to all ships within a state's internal waters and territorial sea, the combination of innocent passage and difficult enforcement means that in practice states often prefer to apply certain laws only to vessels that actually visit a port.

This is reflected in the port state control context, with which the term "port state" is most commonly associated. Port state control is a narrower concept than port state jurisdiction, involving the inspection and assessment of visiting vessels against a range of internationally-agreed standards on matters such as safety and environmental safeguards. ${ }^{18}$ These inspections are generally arranged on a regional basis, so that information can be shared and efforts targeted towards the most high-risk ships. ${ }^{19}$ Port state control is usually provided for in international shipping agreements, ${ }^{20}$ but the

14 UNCLOS, above n 3, arts 29-32 and 95-96.

15 See generally Aldo Chircop and Olof Linden (eds) Places of Refuge for Ships: Emerging Environmental Concerns of a Maritime Custom (Martinus Nijhoff Publishers, Leiden, 2006).

16 More general limitations on prescriptive jurisdiction continue to apply, such as the principle of good faith and the doctrine of abuse of rights: UNCLOS, above $\mathrm{n} 3$, art 300. In addition the principle of proportionality and prohibitions on discrimination against particular flags will impact on the exercise of port state jurisdiction: see Ringbom, above n 2, at 223-230.

17 In the past some authors have argued that under customary international law a port state has no jurisdiction over a vessel's "internal affairs", but this has been convincingly dismissed: see for example A H Charteris "The Legal Position of Merchantmen in Foreign Ports and National Waters" (1920-1921) 1 Brit YB Intl L 45 at 46; Philip C Jessup The Law of Territorial Waters and Maritime Jurisdiction (G A Jennings Co, New York, 1927) at 191-194; McDougal and Burke, above n 8, at 164-165. The concept may still have some relevance as a rule of domestic law in some jurisdictions: see for example Spector v Norwegian Cruise Line Ltd 545 US 119 (2005).

18 See generally Özçayir, above n 2.

19 The first agreement was the Paris MOU, on which other regional memoranda are based: Paris Memorandum of Understanding on Port State Control (adopted 26 January 1982, entered into force 1 July 1982). The relevant instrument in the New Zealand context is the Tokyo MOU: Memorandum of Understanding on Port State Control in the Asia-Pacific Region (adopted 1 December 1993, entered into force 1 April 1994).

20 See for example International Convention for the Safety of Life at Sea (SOLAS) 1184 UNTS 278 (opened for signature 1 November 1974, entered into force 25 May 1980) at reg I-19; International Convention on 
same effect can be achieved by relying on port state jurisdiction more generally. In other words, such provisions merely confirm the existence of port state jurisdiction in a particular context; they do not create it. This is demonstrated by the common practice of taking port state control measures against vessels operating under the flags of states that are not party to the conventions in question. ${ }^{21}$

While port state control arrangements provide the most visible example of port state jurisdiction being exercised in practice, the most challenging issues arise when states use port state jurisdiction to introduce unilateral shipping regulations. As noted above, UNCLOS and customary international law place few restrictions on the use of port state jurisdiction. Therefore, putting aside the rare examples of international conventions that explicitly limit port state jurisdiction, ${ }^{22}$ the most important checks on such unilateral measures are economic and political. ${ }^{23}$ If a port state goes too far beyond the international norm, for example by introducing a law requiring all visiting foreign vessels to carry an expensive wind generation system for use in port, then ship operators may decide to trade elsewhere. Furthermore, the port state in question may receive sharp criticisms from other states that view a multilateral approach under the auspices of the International Maritime Organization (IMO) as a more appropriate avenue for reform.

These considerations carry particular weight in the shipping sector, which on the whole benefits from uniform regulations developed at the international level in order to promote the smooth functioning of international trade. ${ }^{24}$ However, the IMO does not have a monopoly on shipping regulation and has been "hurried along" by port states in the past. ${ }^{25}$ Unless they expressly limit a

the Prevention of Pollution from Ships 19731340 UNTS 184 as modified by the Protocol of 1978 relating thereto (opened for signature 2 November 1973 and 17 February 1978 respectively, entered into force 2 October 1983) [MARPOL] at annex I, reg 2-11.

21 A number of agreements have "no more favourable treatment" clauses which support this practice, see for example MARPOL, above n 20, art 5(4); International Convention on Standards of Training, Certification and Watchkeeping for Seafarers 1361 UNTS 2 (STCW) (opened for signature 7 July 1978, entered into force 28 April 1984), art X(5). See Molenaar, above n 13, at 119-121.

22 See for example MARPOL, above n 20, at annex VI, reg 15(1).

23 For related discussion see for example David Allan Fitch "Unilateral Action Versus Universal Evolution of Safety and Environmental Protection Standards in Maritime Shipping of Hazardous Cargoes" (1979) 20 Harv Intl LJ 127 at 167-173; Alan Khee Jin Tan "The Regulation of Vessel-Source Marine Pollution: Reconciling the Maritime and Coastal State Interests" (1997) 1 Sing J Intl \& Comp L 355 at 375-376; Alan Boyle "EU Unilateralism and the Law of the Sea" (2006) 21 Intl J Mar \& Coast L 15 at 20 and 31.

24 The importance of promoting international approaches in the maritime sector has long been recognised: see Richard A Legatski, "Port State Jurisdiction over Vessel-Source Marine Pollution" (1977) 2 Harv Env LR 448 at 467; Fitch, above n 23, at 144-145; J Peter A Bernhardt "A Schematic Analysis of Vessel-Source Pollution: Prescriptive and Enforcement Regimes in the Law of the Sea Conference" (1979) 20 Virg J Intl L 265 at 268.

25 For example, unilateral action by the European Union in relation to the phasing-out of double-hulled tankers ultimately compelled the IMO to update the international timetable: see Ringbom, above n 2, at 235 and 346-352. 
port state's jurisdiction, the IMO's agreements represent minimum international standards, and a state is free to introduce more stringent standards if it sees fit. ${ }^{26}$ This is further demonstrated by the savings provision included in each port state control memorandum to the effect that it does not limit a party's port state jurisdiction. ${ }^{27}$ Provided the state can justify the measure on political and economic grounds then a measure based on port state jurisdiction will often provide a sound means of unilaterally regulating international merchant shipping.

While examples of such measures remain uncommon, instances of state practice are coming to light more rapidly than in previous decades, particularly as a result of legislation introduced by the European Union and United States. ${ }^{28}$ New Zealand is not a significant port state in terms of vessel movements but its relative isolation, sensitive marine environment, and extensive maritime zones do place the country in a position whereby some unilateral requirements could be justified on policy grounds. A good example is the one provided in Sellers, namely the regulation of safety equipment aboard pleasure $\mathrm{craft}^{29}$ that are passing through New Zealand's expansive zone of responsibility for search and rescue. ${ }^{30}$ However, the decision in Sellers has hampered the deployment by New Zealand of any regulations not based on an international agreement.

\section{THE DECISION IN SELLERS}

The appellant in Sellers was the master of the Nimbus, a Maltese-registered private yacht. He was not granted clearance to leave port by the New Zealand authorities on the basis that he was not carrying a radio or emergency locator beacon in accordance with s 21 of the Maritime Transport Act 1994 (the MTA). This requires the master of a pleasure vessel departing for overseas to satisfy the maritime safety authorities that the vessel is adequately crewed, complies with any relevant Maritime Rules, ${ }^{31}$ and that "the pleasure craft and its safety equipment are adequate for the voyage".

26 Erik J Molenaar "Residual Jurisdiction under IMO Regulatory Conventions" in Henrik Ringbom (ed) Competing Norms in the Law of Marine Environmental Protection: Focus on Ship Safety and Pollution Prevention (Kluwer Law International, London, 1997); Johnson, above n 13, at 43-44; Ringbom, above n 2 , at 222-223.This is reflected in more recent IMO agreements, see for example International Convention on the Control of Harmful Anti-fouling Systems on Ships 1833 UNTS 397 (opened for signature 5 October 2001, entered into force 17 September 2008), art 1(3); International Convention for the Control and Management of Ships' Ballast Water and Sediments (opened for signature 13 February 2004, not yet in force), art 2(3).

27 See for example Paris MOU, above n 19, ss 1.7 and 8.1; Tokyo MOU, above n 19, ss 3.2.2 and 8.1.

28 See Bevan Marten Port State Jurisdiction and the Regulation of International Merchant Shipping (Springer, Berlin, 2013) at ch 7.

29 No legal distinction is made in this article between pleasure craft and other private (for example merchant) vessels.

30 See Sellers v Maritime Safety Inspector, above n 1, at 48-49.

31 These are detailed technical regulations covering a wide range of shipping matters, primarily drawn from standards agreed at the international level. For a full list see <www.maritimenz.govt.nz>. 
Mr Sellers, who was deliberately not carrying the equipment in question on the basis of his personal philosophy of navigation, was prosecuted and convicted in the District Court for a breach of the MTA. He appealed, first to the High Court and then to the Court of Appeal, on the basis of the principle of the freedom of the high seas. From Mr Sellers' perspective, being compelled to carry a radio by the New Zealand authorities was inconsistent with his right to navigate his vessel as he pleased.

The Court of Appeal's decision was given by Keith J, now a Judge of the International Court of Justice. The Court based its decision upon the principle of the exclusive jurisdiction of the flag state over its vessels on the high seas, ${ }^{32}$ as guaranteed by UNCLOS. ${ }^{33}$ It held that the effect of the Maritime Safety Authority's approach to s 21 of the MTA was to interfere with this jurisdiction by requiring safety equipment to be carried beyond New Zealand's internal waters. ${ }^{34}$ The Court did not state that it was never possible for a state to regulate the extraterritorial operations of a foreignflagged vessel, but that this was only possible in a very limited number of situations, as for example when acting to prevent an imminent oil spill. ${ }^{35}$ Extraterritorial jurisdiction based on the effects doctrine was also discussed, and its application ruled out in the context of s 21 as no relevant effects were felt in New Zealand's territory. ${ }^{36}$

The jurisdiction of port states was discussed, but only in relation to their role in enforcing internationally-agreed standards, notably through port state control arrangements. ${ }^{37}$ The Court rightly identified that international agreements such as the International Convention for the Safety of Life at Sea (SOLAS) and the International Convention on the Prevention of Pollution from Ships (MARPOL) place primary responsibility for compliance with the flag state, leaving port states to play a supporting role in enforcement. However, their Honours then used this to support a conclusion that a port state only has prescriptive jurisdiction to the extent provided for under such agreements. To support this the Court concluded that art 21 of UNCLOS, which limits a coastal state's jurisdiction over foreign vessels exercising innocent passage in its territorial sea, demonstrates that a port state has no ability to create its own, unilateral safety obligations. ${ }^{38}$ In other words, if a port state cannot point to UNCLOS or another international agreement, or a widely-

32 Sellers v Maritime Safety Inspector, above n 1, at 46-47.

33 UNCLOS, above n 3, art 92

34 Sellers v Maritime Safety Inspector, above n 1, at 48.

35 At $47-48$.

36 At $49-51$

37 At $51-54$

38 At 54. 
accepted basis of extraterritorial jurisdiction such as the effects doctrine, it has no ability to regulate the vessels visiting its ports. The Court concluded that: ${ }^{39}$

[A] port state has no general power to unilaterally impose its own requirements on foreign ships relating to their construction, their safety and other equipment and their crewing if the requirements are to have effect on the high seas. Any requirements cannot go beyond those generally accepted, especially in the maritime conventions and regulations; ... In addition, any such port state powers relate only to those foreign ships which are in a hazardous state.

Accordingly the Court's view was that the requirements imposed by the maritime safety authorities under s 21 of the MTA had to be in accordance with international law, and thus limited to requirements provided for under internationally agreed rules and standards. ${ }^{40} \mathrm{Mr}$ Sellers' appeal succeeded and his conviction was quashed.

\section{EVERYTHING HAPPENED IN PORT}

The Sellers decision was not incorrect in emphasising the flag state's exclusive jurisdiction over a vessel on the high seas. However, that is not the effect, in legal terms, of a provision like s 21 of the MTA. As the Court noted: ${ }^{41}$

That provision can be seen as doing no more than creating an offence which is committed within New Zealand internal waters, at the point of departure from port, and which can be enforced only by proceedings brought in a New Zealand court, without any related powers being exercisable on the high seas. On that basis, neither the exercise of legislative jurisdiction nor the exercise of judicial jurisdiction over the alleged breaches of it relates to events outside New Zealand or even outside New Zealand internal waters.

This was the right answer. The requirement to carry a radio and locator beacon was applied by way of port state jurisdiction. The vessel was within New Zealand's territory, and subject to New Zealand laws.

However, the Court in Sellers declined to adopt this position on the basis that the real effect of the provision was to qualify the exercise of the freedom to navigate on the high seas, in the instant case because New Zealand's maritime authorities wanted the vessel's radio and locator beacon to be aboard once the vessel left port. ${ }^{42}$ This was certainly true, but it was not the approach taken in legal terms. The Court's concern for the impact of domestic standards on vessels on the high seas is

39 At 57.

40 At $59-62$.

41 At 48 .

42 Davidson reluctantly concludes that this was the right approach: J Scott Davidson "Freedom of Navigation on the High Seas: Sellers v Maritime Safety Inspector" (1999) 14 Intl J Mar \& Coast L 435 at 438-439. 
understandable. However, international law does not prevent a state from declaring that if a vessel wants to visit (or depart from) its ports, it must be carrying specific equipment. The master in Sellers could have jettisoned his newly-purchased radio as soon as he was outside of New Zealand's territorial sea, but he ought to have been compelled to comply with the prescribed safety standards while within New Zealand's jurisdiction.

Section 21 of the MTA reflects a common approach in the context of port state jurisdiction. A requirement is introduced that is static in nature, such as the need to carry a radio. The presence or absence of a radio is unlikely to change; it is either aboard or it is not upon entry to port. Such laws can be seen as a form of continuing offence. The vessel will be progressing through its international voyage in an ongoing breach of the requirement. However, instead of trying to determine when the problem first arose, the port state simply assesses compliance with the requirement while the vessel is in port, and declares the breach to have occurred at that point in time. Although the expectation is that the vessel will comply with the requirement, and then continue in a state of compliance once it leaves port, in legal terms the port state is concerned only with what takes place within its jurisdiction.

The approach is particularly effective where the requirement is fundamental to the vessel that it could never be removed in practice, such as the need to have a double hull. An influential port state can thus introduce a unilateral standard that in practical terms is enormously significant to a shipping operation. This reinforces the importance of the economic and political limitations on the introduction of unilateral standards, referred to above, as a means of keeping most shipping regulation within the multilateral programme of the IMO.

As the foregoing suggests, port state jurisdiction works best when it concerns only matters that can be assessed as having been breached within the port state's territory. Far more controversial issues arise when a port state attempts to regulate the operations of foreign vessels taking place beyond the territorial sea. As this was not the case in Sellers (at least in my view) these issues are not the focus of this article. Nonetheless, it is important to note that port states do occasionally attempt to regulate, even if indirectly, the extraterritorial operations of foreign vessels in a manner that goes beyond the limits described by the Court of Appeal. ${ }^{43}$ When this occurs, the port state in question will not argue that they are attempting to dictate the extraterritorial operations of foreign vessels. They will further accept that the flag state has exclusive jurisdiction on the high seas and that their coastal state jurisdiction is limited by UNCLOS. Instead they will argue that, as there is no right of access to a state's ports under international law, ${ }^{44}$ they are simply introducing conditions of port entry that the vessel's operator has chosen to accept. If a vessel has not operated in accordance

43 See Marten, above n 28, at ch 4.

44 A V Lowe "The Right of Entry into Maritime Ports in International Law" (1977) 14 San Diego LR 597. 
with those conditions en route, then it will either be denied permission to enter port, or subject to sanctions on arrival. ${ }^{45}$

The facts of Sellers disclosed a situation in which it would have been more appropriate for a court to look to the formal jurisdictional basis of the requirement as opposed to its intended effects. The port state has the necessary (territorial) jurisdiction, the foreign vessel has voluntarily submitted to its rules, and remains free to operate as it pleases following departure. Port state control measures around the world rely on this approach daily to ensure that vessels remain up to standard. This process, on which the maritime world depends so heavily, could not work in relation to the vessels of non-parties if the Sellers approach was taken.

\section{PORT STATES' POWERS ARE BROADER}

The more significant problem with the Sellers decision concerns the extent of a port state's jurisdiction. Instead of taking a state's largely unfettered territorial jurisdiction over visiting foreign vessels as its starting point, the Court looked to various international maritime agreements, and held those up as representing the extent of a port state's prescriptive jurisdiction.

The correct position is that port state jurisdiction is not comprehensively dealt with in any international convention. The subject of a state's authority over vessels visiting its ports was deliberately left out of UNCLOS, and the concept continues to be governed mainly by customary international law. ${ }^{46}$ Conventions such as SOLAS and MARPOL provide an enforcement function for port states but, as noted above, this does not limit their ability to prescribe and enforce more stringent standards than those agreed to. While the aim of such conventions may be to harmonise international maritime law, this is not sufficient to limit the prescriptive jurisdiction of port states without explicit words to this effect. ${ }^{47}$ Only in rare cases will a provision of an international convention expressly limit port state jurisdiction, as in the case of MARPOL setting a maximum limit on vessel emissions. ${ }^{48}$ By contrast, parties to the 1923 convention on ports mentioned in the Court of Appeal's judgment grant non-discriminatory port access to other parties' vessels. The agreement contains no provisions limiting the scope of any requirements the port state may decide to apply to the vessels granted such access. ${ }^{49}$

45 For further discussion see Molenaar, above n 2; Henrik Ringbom "Global Problem - Regional Solution? International Law Reflections on an EU CO2 Emissions Trading Scheme for Ships" (2011) 26 Intl J Mar \& Coast L 613 .

46 See Molenaar, above n 13, at 94; Anderson, above n 13, at 342; Churchill and Lowe, above n 8, 60-61; Johnson, above n 13, 35 and 46.

47 Ringbom, above n 2, at 219-223; Johnson, above n 14, at 43-44; Boyle, above n 23, s24-25.

48 See for example MARPOL, above n 20, at annex VI, reg 15(1).

49 Sellers v Maritime Safety Inspector, above n 1, at 49; Convention and Statute on the International Regime of Maritime Ports 58 LNTS 285 (opened for signature 9 December 1923, entered into force 26 July 1926)). 
Molenaar's criticism of the decision is summarised as follows: ${ }^{50}$

The Court appears to have: misinterpreted Article 211(3) of the LOS Convention, failed to discuss the absence of a right of access to ports under general international law and Article 25(2) of the LOS Convention, incorrectly linking the notion of "generally accepted" to port state jurisdiction, misinterpreted the function of regional merchant shipping PSC regimes, and failed to refer to the savings clauses therein.

As Ringbom notes, following the Court's logic would mean that the majority of the world's port states are acting unlawfully in applying their domestic shipping standards. ${ }^{51}$

\section{OVERTURNING SELLERS}

As demonstrated by the discussion above, I believe that the interpretation of the international law relating to port state jurisdiction provided by Sellers is incorrect. However, the decision also has an ongoing negative impact in the domestic law context, effectively hamstringing any attempt to regulate foreign shipping on a unilateral basis. Although New Zealand is unlikely to have the desire (or the international clout) to introduce too many laws of this kind, where they are justified on sound policy grounds the option should be available.

As Sellers demonstrates, maritime legislation in New Zealand must be interpreted in light of international law. ${ }^{52}$ If the maritime industry were able to be regulated by nothing but unambiguous statutory sections, then this exercise might not have much impact on any expressly unilateral exercises of port state jurisdiction. However, the complex nature of the shipping sector requires a range of broadly-worded provisions, secondary legislation (notably the Maritime Rules), ${ }^{53}$ and discretionary powers to account for all foreseeable circumstances. Since 1998, these provisions and powers have had to be read down to meet the Sellers interpretation of New Zealand's port state

50 Molenaar, above n 2, at 232 (references omitted); see also Erik J Molenaar, Alex G Oude Elferink and Denise Prevost Study on the Labour Market and Employment Conditions in Intra-Community Regular Maritime Transport Services Carried Out by Ships under Member States' or Third Countries' Flags: Aspects of International Law (Netherlands Institute for the Law of the Sea, University of Utrecht, Utrecht, 2008) at 38-39.

51 Ringbom, above n 2, at 339.

52 Sellers v Maritime Safety Inspector, above n 1, at 57-62. The decision formed part of a wider movement, spearheaded by Keith J, towards the greater acceptance of international law's place within New Zealand's domestic law: see Claudia Geiringer "Tavita and All That: Confronting the Confusion Surrounding Unincorporated Treaties and Administrative Law" (2004) 21 NZULR 66, especially 76-77 and 79-80 and 104-105; John McGrath "Commentary: International Law's Recent Influence on Domestic Court Decisions in New Zealand" in Claudia Geiringer and Dean R Knight (eds) Seeing the World Whole: Essays in Honour of Sir Kenneth Keith (Victoria University Press, Wellington, 2008) 136 at 142-144.

53 These are sourced primarily from international conventions like SOLAS and MARPOL but including domestic requirements, take up a lot of space on the surveyor's shelf. They are technical, detailed, and everevolving. 
jurisdiction. For example, the need for foreign pleasure vessels to carry a radio and locator beacon, formerly made compulsory under s 21 of the MTA, is now merely a non-binding recommendation.

The Sellers interpretation will also have an ongoing effect on new legislation. ${ }^{54}$ Recently the Government has introduced a Bill that, from 2016, will see all fishing vessels in New Zealand's maritime zones operate under the New Zealand flag. ${ }^{55}$ As an interim measure foreign flagged vessels will continue to be licensed to operate, but the Minister may consider ${ }^{56}$

any risk associated with fisheries management, employment, vessel safety, or compliance with maritime rules relating to pollution and the discharge of waste material from vessels that the chief executive considers would be likely to result if the vessel were to be registered.

Reading this requirement in light of Sellers it could be argued that the considerations listed must relate only to standards based on international agreements. If the chief executive anticipated a risk relating to safety equipment that was not present aboard a foreign vessel, its operator could respond that New Zealand has no jurisdiction to prescribe such a requirement, and cannot therefore introduce one through the "back door" in this way. Given that the fishing industry is subject to very few safety-related rules agreed to at the international level, ${ }^{57}$ this has the potential to hamper New Zealand's intentions of promoting high standards in the sector.

In terms of overturning Sellers, one option would be to take an analogous case through the appellate courts in the hope of a different result. This is feasible, but subject to the uncertainties of litigation. A better approach would be to draw the decision's sting by way of a legislative amendment. This would best be achieved by including a provision in the MTA that reasserts New Zealand's port state jurisdiction and ability to regulate foreign vessels in a unilateral manner if desired. The provision should make clear that rules affecting foreign shipping can be made in situations where no equivalent international standards exist. It should also include wording to the effect that regulators may introduce provisions that are more stringent than any relevant international standards when framing Maritime Rules and other secondary legislation, provided certain criteria are met. For example, that the intention to introduce more stringent standards is expressly stated in the rules, and that the standards are as consistent as practicable with the objects and purpose of the relevant international standard.

54 See for example New Zealand Steel Mining Ltd "Submission of New Zealand Steel Mining Ltd to the Transport and Industrial Relations Committee on the Marine Legislation Bill" (12 October 2012) at [13.5] and [40], relying on the Sellers decision to oppose a change to the law relating to the loading of ships.

55 Fisheries (Foreign Charter Vessels and Other Matters) Amendment Bill (75-2).

56 At $\mathrm{cl} 4$.

57 The Chief Executive could attempt to rely on the fishing licence conditions that may be imposed under UNCLOS to provide the necessary jurisdictional basis, but even this approach could arguably be read down if Sellers-style reasoning is followed: UNCLOS, above n 3, art 64. 
I proposed an amendment to this effect at the Select Committee stage of the Marine Legislation Bill. ${ }^{58}$ However, the advice of the Ministry was that this was too complex a matter to be dealt with in the context of the Bill, ${ }^{59}$ and the suggestion was not taken up by the Committee in its report. An opportunity for reform will no doubt arise in time. After all, it should take only one legislative amendment with a background critical of Sellers to convince a court that it can overlook the port state jurisdiction aspects of the decision: New Zealand's Parliament would have in effect rejected the Court's interpretation of international law on that point. In the meantime New Zealand's maritime law remains tangled in the rigging of the Nimbus.

58 Bevan Marten "Submission on the Maritime Legislation Bill" (8 October 2012) 1-4.

59 Ministry of Transport and Ministry for the Environment "Marine Legislation Bill 2012: Report of the Ministry of Transport and the Ministry for the Environment" (15 November 2012) at 66. 
